\title{
Shaker Zahra Author Bibliometric Study - Analysis of Scientific Publications from 1985 until 2014
}

Arlan Silva ${ }^{1} \&$ Academic Board of Revista de Negócios²

${ }^{1}$ Universidade Regional de Blumenau - FURB - e-mail: arlan5@hotmail.com

2Universidade Regional de Blumenau - FURB - e-mail: rn@furb.br

\section{KEYWORDS}

Shaker Zahra, Entrepreneurship, Bibliometric Study, Scientific Publications, Bibliometric.

Received 19.05.2016

Revised 01.06.2016

Accepted 17.06. 2016

ISSN 1980-4431

Double blind review

\begin{abstract}
The study aims to demonstrate through a bibliometric study, an analysis of academic, scientific and technical publications developed by Shaker Zahra between the years 1985-2014, representing 29 years of study. To enhance this objective, we sought in the first instance to a bibliographic description of bibliometrics, entrepreneurship and the relationship between them. After this, was demonstrated academic and professional history Zahra, describing their field. In sequence, it was presented the methodology of the study, which had focused its characterization longitudinal and quantitative research, which allowed the development of bibliometric analysis. The final part included the description of limitations and proposals for future studies, closing the research, with conclusions and references. The study was developed through the analysis of 160 scientific papers published by Shaker Zahra in partnership with other researchers in high-impact journals and academic and scientific importance were obtained at Portal Capes and Google Scholar Portal.
\end{abstract}

\section{Introduction}

The development of scientific research establishes milestones and principles for the formation of ideas, methods and behaviors. This brings a huge bag of thoughts and understanding, making new theories are created, new strategies and new research criteria. Finally, scientific research allows new revolutions occur as it relates to discovery, invention and innovation.

Conduct scientific research is therefore an event that lets you know how people and organizations think and act as is also set new technical and scientific parameters for the development of science itself. The reflection of this is the creation of new scientific structures and new formulas, classifications and theories in order to allow the emergence of definitions and interpretations that did not exist in the social or environmental human.

For this reason, it is important to know and investigate who develops these scientific efforts that profile these people carry with them, to investigate issues that desires, curiosities and interests have and who develop and share their ideas and experiences. In short, this leads to know and to know who these people are and how they shape the academic life of these curious investigators of human and social science.

With the interest in presenting answers to these questions, this study is characterized as a longitudinal study aims to demonstrate through bibliometric analysis, the academic life of one of the most renowned scientific researchers in the 
field of entrepreneurship - Professor Shaker Zahra . In order to make an investigation of all the papers that has developed and published in the period comprising between the years 1985-2014, representing 29 years of studies and academic and technical research.

It is known in advance that their research already exceed more than 250 different studies, in which they all had high level of academic interest, being published in high impact journals and scientific representation. For the study in question, after a thorough conference published articles, gave a final sample of 160 scientific articles, in which they went through a general conference of data and information, allowing you to arrive the responses of the study presented.

The structure of this study occurs through three stages, the first being the most bibliographic elaboration of general understandings of concepts of bibliometrics and entrepreneurship, the second being to the methodology to be used and the third phase, shown by survey data held, showing the quantitative results and making analysis by descriptive technique.

Finally, the study also presents its considerations, limitations and proposals for future studies, describing in general, the direction of the study, the difficulties that had in its implementation and the opportunities.

\section{Bibliometrics and Entrepreneurial Research}

It is known saying that entrepreneurship has acquired an important highlight in the last 30 years, influencing society's behavioral change and, for that, if analyzed in the macro context, people, organizations and countries had to reinvent and create new ways of doing things and to relate to their environment. This required that arose and were called practices in modern society, new attitudes, behaviors, thoughts and forms of relationship, aiming adaptability, 'reinvention' and 'recreation' of economic systems and new personal and professional profiles.

If directed to the field of science, to better learn about this social transformation, it is necessary to know historical information of academic research on the recent interpretations of entrepreneurship and that these interpretations have contributed to the development of scientific research.

As for the bibliometric method, which is a mapping tool of evolution and social change as it relates to literary research, this method acquires real importance in numerical research data, seeking to demonstrate the importance of use and the influence of their technical evolution academic and literary research. Using publications counting techniques, subjects studied, developed variables, periodicity, authorship and co-authorships and investigated population, bibliometrics seeks to make a general survey, giving answers that most influenced the researchers in their past investigations and which may influence investigations future.

Having therefore these two issues as the basis of the study of this research is carried out, are based on first, more historical information about bibliometrics and entrepreneurial terms, getting to a second stage, within its own line of analysis, the description more conceptual and interpretative these issues.

\subsection{Brief history understanding the method} bibliometric

The term bibliometrics as well is currently known, had its initial studies that occurred more than 80 years, when three researchers created their own frequency measurement and analysis techniques. Known as laws, these techniques came to allow a better understanding of the methodology of literary data count published in journals. The first technique Zipf's Law call attempts to measure the frequency of words. The second technique known as Lotka Law, is intended to measure the productivity of authors, while the third technique, known as Bradford's Law Act, is intended to measure the productivity of journals (LIMA, 1984).

With the passage of time, these laws were moving away from each other as to its applicability, getting the Bradford Law as the best known and most used, due to the application of static and dynamic techniques in data analysis. Lima (1984) says that arose in 1934, the Bradford Law focused mainly on studying the literature by examining the quantity, frequency and productivity of the publication of journals and eventually becoming the best known, having been used numerous times in various fields of science.

Over the years, the Law of Bradford was being improved by several other scientific researches. Lima (1984) sets out 14 researchers

Revista de Negócios, v. 20, n. 4, p. 44-6o, October, 2015. 
who sought to improve the application of the techniques of Bradford Law. They are: Vickery (1948), Garfield (1967), Brookes (1969), Fairthorne (1969), Goffman (1969), Pritchard (1969), Saracevic (1970), Pinero L. (1972), Hjerppe (1978), Braga (1972), Figueiredo (1973), Roberts (1981), Pinheiro (1982) and Maya (1982). These studies have allowed a better understanding of the applicability of Bradford Law.

What is known is that it was through this law and the initial studies by Otlets and complemented by Pritchard in 1969 that the term 'bibliometric' arose where it was decided that this would be a technique to be used to describe the studies that seek quantify the processes of written communication, applying mathematical, static and dynamic methods in information count in books, journals and other media (LIMA, 1984).

In 1977, Braga created the static and dynamic methods of application of bibliometrics, seeking to better structure the application of its techniques. These techniques have their particularities and allowed better targeting of studies. For example, the static method, its function is primarily to deal with the parameters regarding the size and distribution of the literature (authors, titles, articles, journals, etc.) in a particular period, while the dynamic method, the commitment is to deal with growth and the exchange rate of the same parameters (authors, titles, articles, periodicals, etc.) used by the static method (BRAGA, 1977).

Lima (1984) also used this interpretation, arguing own thoughts on the static and dynamic method. This says that the static technique turns in measuring in a determined period of time, parameters related to the size and distribution of the amount of authors, securities, documents and publications while dynamic methods seek to measure growth and the rate of change of these parameters.

Of course, if perceived by the evolution of studies that bring the meaning of bibliometrics, these were very important to clarify your purpose and applicability, but concentrating only the Bradford Law and its principles, these more than 80 years has passed its creation, still perceive a lack of understanding as to its real purpose and or applicability. As much as the same has already been used in many scientific researches, yet there is a lack of clarity and accuracy the importance of the results that their analysis let you create.

\subsubsection{Concepts and basic interpretations of bibliometric method}

The realization of bibliometric research is by studies in bibliographic databases, involving the analysis of quantitative aspects, aiming to spread the use of the information published. This conveys the importance of bibliometric study in the analysis of literary publication, as this allows it to be served the need to know and evaluate indepth way, productivity and quality of scientific research.

Ikpaahindli (1985), he says Bibliometrics is a generic term that describes a number of techniques that seek to quantify the written communication process. These techniques have been used to identify the most productive authors, identifying paradigms in science, fusion and fission of scientific disciplines and in identifying the most productive journals in different fields, allowing demonstrate a thorough examination of published issues, adopting and adopting standards communication publishing specific writing and authors.

Ravelli et al. (2009) also values this thinking, noting that the importance of bibliometric studies is supported by the need to know and evaluate the productivity and quality of research actors (authors / researchers), allowing the detection of dispersion models and behavior patterns citations in scientific production. Such models and behavior patterns help to understand how scientific knowledge is widespread and embedded between the actors and their peers, as well as among the general public (RAVELLI, et al., 2009).

Already Spinak (1998, p. 142) provides another understanding of bibliometrics, saying that this is considered "is a discipline with a multidisciplinary range, since analyzes one of the most important aspects and objectives of the printed communication," in which is can It is considered by the numerical count of existing data in publications made in different periods. This technique allows the development of relevant analysis and even, often surprising, providing analysis that go in depth about the subject that you study.

Soft-Chapula (1998, p. 135) say that bibliometrics as to their type, counts among study subjects with

Revista de Negócios, v. 20, n. 4, p. 44-6o, October, 2015. 
periodicals or journals, articles and authors, and the measure is verified by simple frequency count.

The bibliometrics can be considered an excellent tool for quantitative studies, as its goal is to develop increasingly reliable indicators as the demonstration of the data being analyzed. She bibliographic catalogs, structural data of titles, keywords, subjects of study, applied research methods, analyzed profile and publishing bases, performing demonstrations that allow to know the essence of scientific publication.

Finally, when studying bibliometrics, it is understood that it is considered as a methodology to develop indicators on literary production, covering various fields of study and having the function of creating quantitative data bibliographic publications already undertaken in order to better explain the way that the research was adopted.

\subsection{History recent entrepreneurship}

Developments in entrepreneurship studies can be marked by numerous discoveries, whether scientific or technological that marked the course of time the evolution of society.

More recently, the 1980s was marked by a strong deepening in scientific research, especially one that was related investigations focused on the theme entrepreneurship, making it one of the main subjects of debate and whetting the interest of the academic community to describe how it forms the behavioral characteristics of the entrepreneur and as is the emergence of companies process. Several were scholars and researchers who presented arguments and understanding at this time, trying to answer mainly as forms and is characterized entrepreneurship and entrepreneurial individual.

Studies such as McClelland (1961) who tried to describe who is the entrepreneur; Schumpeter (1964) who said that this phenomenon occurs as an act of innovation; Drucker (1970) who argued that the enterprising person is one who venture into any business; Van de Ven, Hudson and Schroeder (1984), Churchill and Lewis (1985) have studied the process of creating companies, Gartner (1985), Bygrave (1989a, 1989b), Bygrave and Hofer (1991), Filion (1991) and Bruyat (1994) with studies on the multidimensional characteristics and the dynamics of this process; Zahra (1986) with corporate entrepreneurship; Low and
MacMillan (1988) who described as an entrepreneur acts and Carter, Gartner and Reynolds (1996) with the concept of organization were valid and important for the whitening of such claims, but even so, however these results were surprising, according says Oliveira (2012) so it was not possible to trace a psychological profile of the entrepreneur.

This is justified by the fact that people are then changing and adapting to new scenarios, whether social or environmental, having to express different behaviors for each situation presented, so exposed, their anxieties, desires, expectations, interests, individual goals and dreams. What is known is that entrepreneurship allows people can invent and reinvent themselves, improving their adaptability to the environment and the basic conditions for survival and social development.

\subsubsection{Conceptual understandings about entrepreneurship}

The phenomenon of entrepreneurship, a more empirical view, comes down to a social study, seeking to know how people act in the sense of thoughts, habits, desires and social values. This alone, turns to an analysis of social, cultural and economic environment in order to allow people the knowledge of their capabilities, their actions and the way they manage their interests.

Gimenez et al. (in:. Souza, 2001, p 22) comments that entrepreneurship in the various approaches, is seen as the search for "tangible and intangible results of a person with creative skills, being a complex function of life experiences, opportunities, skills and individual capacity and that the exercise is inherent to the variable 'risk', both in your life and in your career. " Ferreira and Mattos (2003) do know that entrepreneurship is seen as an act of undertaking has the task or duty, to develop processes in different scenarios, causing changes in economic systems through innovations brought by individuals who generate and or respond to opportunities economic value creators.

Pereira and Santos (1995) constitute entrepreneurship as one of the management models that stand out in this period of transition and the emergence of new paradigms. The characterization of entrepreneurship as a suitable new management model to new paradigms (economic, political, social, technological,

Revista de Negócios, v. 20, n. 4, p. 44-6o, October, 2015. 
cultural, etc.) is evidenced by the growing literature, especially from the second half of the 1980s, a period that Professor Shaker Zahra also begins its academic and scientific publications.

Undertake can not be seen only as the act of creating a new business. Undertake in Schumpeter's view, should develop actions that will turn the creation of innovation, invention and development of new models, new paradigms and new ideas. Undertake is to develop a new method for the evolution of culture, society and a certain geographic space technology. Schumpeter (1964) emphasizes the importance of entrepreneurship to society, saying that undertake is to introduce innovation, linking this to the concept known as 'creative destruction' (replacement of old methods and processes for new), as the main driver of economic growth.

Already, Carland et al. (1984) says that entrepreneurship is linked to the concept of competence, since the formation of the entrepreneur should seek to acquire knowledge, skills, experience, creative and innovative capacity. Undertake is therefore to invent and reinvent, it is to create something of value that will benefit both its creator and society. It isto develop ideas that add value for the exploitation of knowledge, to facilitate economic actions, is above all, be different in creativity, communication and attitude. Zahra (2003) also says that

entrepreneurship at the level collaboration also involves taking the additional risks placed through partnerships with others.

By this thinking, entrepreneurship is a study of a phenomenon that goes far beyond just form new ideas and new economic attitudes. It comes with the task of creating a new society, a new thinking and a new system of capabilities, envisioning allow social, cultural, political and economic environment in which the company is formed.

\subsection{USE OF bibliometrics IN ENTREPRENEURSHIP STUDIES}

To study entrepreneurship, which seeks to know is how this develops and interferes with people's daily lives. Through its actions, it is correct to say that the social behavior tends to change and transform. Already bibliometrics is worth precisely these actions to map the way that entrepreneurship is taking when carrying out academic research.
Giarola et al. (2013) states that the identification work on the entrepreneurship process [...] contributes both to the academic world as to the practical, because it creates a better understanding of management initiatives, as well as support and identify the most relevant points in each case.

The relationship which is therefore between the study of entrepreneurship and the use of bibliometric method helps to guide the academic research, is seen by the scientific point of view, because the connection between them transpires the techniques of static and dynamics of developed investigations.

Among the numerous studies that have been developed uniting bibliometrics with entrepreneurship, they all contributed in some way to map the path that was taking the survey. Some national bibliometric investigations that can be cited as examples of this practice are: women's entrepreneurship (Silveira, 2008), entrepreneurship in social business (Iizuka et al, 2014), strategic formation of small companies (ROCHA et al, 2011), entrepreneurial behavior (BRANCHER; dE OLIVEIRA; Roncon, 2012) (. OLIVEIRA et al, 2014), entrepreneurial marketing, research in entrepreneurship in Enanpad (MOREIRA; MOREIRA; SILVA, 2014)., entrepreneurship technological based incubators (Martins et al, 2014 ), entrepreneurship in hospitality (ALMEIDA; ANDALÉCIO, 2012) and intrapreneurship innovation (WERUTSKI et al, 2012).

These can be some examples of the relationship between the two sciences bibliometrics and entrepreneurship, where the first is considered a great tool to know and study the most important work in the area and new gaps research findings (SILVA; NASSIF, 2014).

\section{Shaker Zahra}

The choice to analyze the publications of Professor Shaker Zahra, settled for being considered one of the most renowned the world's scientific researchers in the field of entrepreneurship, searching through this theme, more than fifty other related issues, in which it has a highlighted research conducted with the following directions: guidance and strategic process, financial performance, international entrepreneurship, corporate entrepreneurship,

Revista de Negócios, v. 20, n. 4, p. 44-6o, October, 2015. 
governance, internationalization, family entrepreneurship and business opportunities.

The amount of academic research developed by Zahra is such that between 19962014, his works were extremely important for the advancement of other academic research, scientific and technical, receiving more than fortytwo thousand citations. In terms of publication of scientific articles through Google searches done to School portal, gave an initial list of 257 titles of scientific papers published by Zahra over 29 years of academic studies.

Being a professor in entrepreneurship courses and strategy at the University of Minnesota, United States, Zahra is also heads the school management Carlson of Management in own University Minnesota. The academic and professional background is wide and interesting, and has served on the editorial boards of more than 25 professional journals. He received the awards for Best Research numerous magazines, as well as teaching awards, including best teacher in the MBA program and a mentoring award. He was the keynote speaker for more than 40 conferences and conventions and also acts as a consultant in both the United States and other countries for the largest technology companies in the world.

The themes that investigate are: entrepreneurship and national politics in global industries technology based, entrepreneurship international and corporat entrepreneurship, creation knowledge, absorptive capacity and conversion and also knowledge entrepreneurship and capacity development in industries global emerging. In addition, Zahra also research robotics, software applications, global mobile applications, the video game, the pharmaceutical industry and nanotechnology.

In addition to concentrating his research mainly in the US, Shaker Zahra also develops projects in China, Swaziland, Brazil, India, Morocco, South Korea, Sweden, Denmark, Italy and Spain, making use, through their studies, various methods and theories and multiple levels of analysis.

The academic recognition and technical of Shaker Zahra has is huge, which has given him several awards, honors and merits, including three titles Ph.D., two in Sweden and one in Belgium. Among the many awards he received in 2014, stands the Global Award for Research in
Entrepreneurship.

\section{Methodology}

This study, considered bibliometric and longitudinal character, presents both descriptive fundamentals as well as quantitative. Knowing that bibliometrics evaluates, over time, the way that scientific research has taken, longitudinal research is concentrated, according to Remenyi et al. (1998) in studying the phenomenon search for a substantial period of time and the researcher studied the phenomenon caused by changes in time.

Descriptive grounds enable know interpretations of the responses obtained in the survey while the quantitative fundamentals show through charts, tables and network structure, the numerical and structural mapping of research conducted.

It was used as a source of research data, the Journal Portal CAPES and Google Scholar Portal. Having acquired an initial list of 257 scientific articles via Google Scholar Portal itself, in the field quotes after general conference authoring Shaker Zahra, obtained a list of 209 valid surveys and available to obtain and bibliometric analysis. After a search made in both mentioned portals, gave the final PDF file, and 160 a total scientific articles to be analyzed, representing $76.55 \%$ of the 209 items displayed on the bottom listing. These articles are published in high-impact academic journals from 1985 to 2014, representing 29 years of academic and scientific research.

In bibliometric study analyzed the number of publications per year, the general co-author, the main author with one co-author, with two coauthors and co-authors 3. Were also analyzed the gender of the co-authorships, Periodicals and country of publication, the field of study, the keywords, the variables set - dependent and independent, the type of research, methods and types of analysis, and at the end, the profile of the studied population was defined as the sample of each investigation.

The numerical and quantitative data occurred through tables and networks using the Office Excel 2013 software and Ucinet 6. In each presented statement follows a descriptive analysis, enforcing the interpretation of what is researched.

Revista de Negócios, v. 20, n. 4, p. 44-6o, October, 2015. 


\section{Data Analysis}

Research and presentation of research data, which refer to the history of academic and scientific publications of the author Shaker Zahra allowed at the end of data collection, were obtained a total of 160 jobs for analysis.

For this number of jobs, investigations have turned the search for legitimate file with the Portal Google Scholar and the Journal Portal Higher Education Personnel Improvement Coordination - CAPES. The search procedure of these files obeyed the rule to display the title of the work and then obtaining the electronic file.

Obtaining 160 electronic files determined the activities of the first data collection phase, and this quantitative scientific articles represented $76.55 \%$ of the total of 209 available last filtering performed publications list also obtained in Google Scholar Portal. The second phase was the knowledge, determination and the counting of data, in order to have available, the main issues that would serve to further bibliometric analysis of the data that would be characterized as the third phase of this study.

Initially using the software Data tab spreadsheet Excel 13, were transcribed the information contained in the articles, which are divided into two main groups: 1 group) identification of the title and introductory matters involving authorship, journal name, co-author, country publication, year of publication, field of study and keywords; 2nd group) identification method involving dependent and independent variables, type of research, analysis methods, software used, population profile, sample number, basic theory and type of analysis.

With the completion of the transcription of data, began the bibliometric analysis, characterizing is as the third phase of the study. This analysis allows various information about the studies carried out by Zahra. This information is: publications produced per year and their representativeness; authored and co-authored and lead author of networks with general coauthored with 1 co-author, co-authors 2 and 3 coauthors with the help of software UCINET 6; central themes of study; periodic the name used by Shaker Zahra and his co-authors; most cited keywords; dependent and independent variables; types of research, analysis or methods used and methodological techniques and main profiles and the number of the interviewed sample.

In the final phase, it was also pointed out some limitations that are realized in the realization and execution of this study and also an indication of future research proposals based on the knowledge acquired by the developed analysis.

\subsection{Presentation of results}

The first information displayed is the year and the total number of publications and the corresponding gradual representative each period. To know this information, Table 1 shows the results of this subject.

Table 1 - Year of publication, total publications and representativeness

\begin{tabular}{l|l|l}
\hline $\begin{array}{l}\text { Year } \\
\text { Publication }\end{array}$ & $\begin{array}{l}\text { of Potal Publications } \\
\text { Analyzed }\end{array}$ & $\begin{array}{l}\% \\
\text { Representation }\end{array}$ \\
\hline 1985 & 1 publication & $0.63 \%$ \\
\hline 1986 & 1 publication & $0.63 \%$ \\
\hline 1987 & 3 posts & $1.88 \%$ \\
\hline 1989 & 4 posts & $2.50 \%$ \\
\hline nineteen ninety & 3 posts & $1.88 \%$ \\
\hline 1991 & 2 posts & $1.25 \%$ \\
\hline 1992 & 1 publication & $0.62 \%$ \\
\hline 1993 & 8 posts & $5.00 \%$ \\
\hline 1994 & 4 posts & $2.50 \%$ \\
\hline 1995 & 3 posts & $1.88 \%$ \\
\hline 1996 th & 3 posts & $1.88 \%$ \\
\hline 1997 & 1 publication & $0.62 \%$ \\
\hline 1998 & 3 posts & $1.88 \%$ \\
\hline 1999 & 8 posts & $5.00 \%$ \\
\hline 2000 & 10 publications & $6.25 \%$ \\
\hline 2001 & 5 posts & $3.12 \%$ \\
\hline 2002 & 10 publications & $6.25 \%$ \\
\hline 2003 & 10 publications & $6.25 \%$ \\
\hline 2004 & 4 posts & $2.50 \%$ \\
\hline 2005 & 11 publications & $6.87 \%$ \\
\hline 2006 & 8 posts & $5.00 \%$ \\
\hline 2007 & 10 publications & $6.25 \%$ \\
\hline 008 & 8 posts & $5.00 \%$ \\
\hline 2009 & 8 posts & $5.00 \%$ \\
\hline 2010 & 3 posts & $1.88 \%$ \\
\hline 2011 & 9 publications & $5.62 \%$ \\
\hline 2012 & 7 posts & $4.37 \%$ \\
\hline 2013 & 7 posts & $4.37 \%$ \\
\hline Total & 5 posts & $3.12 \%$ \\
\hline Solr & 160 publications & $\mathbf{1 0 0 . 0 \%}$ \\
\hline
\end{tabular}

Source: Adapted by the author. July / 2015. 
In Table 1 are marked years that there were more publications developed by Zahra in partnership with its co-authors. These statements let you know that periods of major publications were those with quantity greater than 1 digit, with the highlight the years 2000, 2002, 2003 and 2007, all of these 10 publications each. The overall highlight of the period was in 2005 , where it contributed to 11 publications. In summation of the respective five years, there has been a total of 51 publications, representing $31.88 \%$ of 160 publications were analyzed.

For countries in which publications were carried out, the United States is considered the leading country with a total of 154 research and developed publications coming in sequence, Britain, 3 publications, and finally, Denmark, Scotland and Sweden, with only one publication each.

In relation to the total number of publications made by Shaker Zahra with other coauthors, these were represented by 123 research involving 118 researchers / coauthors. These were represented by $83.90 \%$ of men and $16.10 \%$ women, determining that the studies by Zahra were mainly supported in achieving and training for people male. Table 2 shows how these coauthors were distributed in the work performed.

Table 2 - coauthors quantity published scientific article

\begin{tabular}{c|c}
\hline $\begin{array}{c}\text { Number of authors publishing } \\
\text { with Shaker Zahra }\end{array}$ & $\begin{array}{c}\text { Number of } \\
\text { Publications }\end{array}$ \\
\hline $\begin{array}{c}\text { Articles with exclusive } \\
\text { publication }\end{array}$ & 37 \\
\hline Articles with 1 co-author & 50 \\
\hline Articles with 2 co-authors & 57 \\
\hline Articles with 3 co-authors or \\
more
\end{tabular}

Source: Adapted by the author. July / 2015.

Observing table 2, it is clear that Zahra followed the trend to develop his studies on the participation of at least two co-authors, which makes sense in general terms, the extent and complexity of the studies, requiring more researchers involved. This occurred in 57 studies involving 70 co-authors, as follows: $80 \%$ were men and 20\% were women, proving again that Zahra develops and publishes its more studies in partnership with men than women.

In the statement of authorship and coauthorship, it was decided to develop a network structure in which was made in four models. These followed the demonstration of 160 publications by Zahra with all co-authors statements 1, 2 and 3. Figures 1, 2, 3 and 4 show these models.

\section{Figure 1 - Structure of nets - Authorship and general co-authoring}

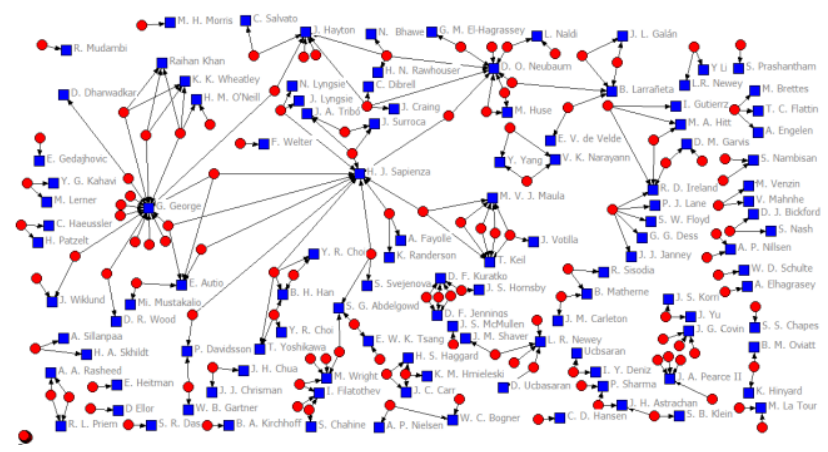

Source: Ucinet. July / 2015.

It is felt that the connection and interconnection between authorship and coauthorship, in the general framework, allows the formation of three major networks, involving three main co-authors in which Zahra sought to publish more. The first network is G. George, HJ Sapienza interconnecting with and therefore with OD Neubaum.

One can see that there is a strong relationship between Zahra's research with these co-authors and that through them, several other small networks are formed, structured as illustrated. An example of this is precisely the relationship among Zahra, George and Neubaum with J. Hayton, allowing the formation of a fourth network and understanding that there is a scientific dialogue between the initial three researchers with this room researcher.

Figure 2 - Structure of nets - Authored with 1 coauthor 


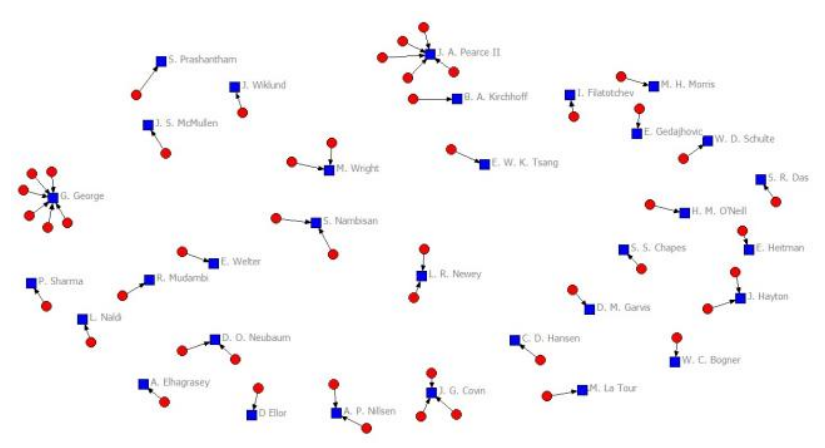

Source: Ucinet. July / 2015.

In Figure 2, indicating Zahra publications with coauthor 1 , it is clear that two are the coauthors cited, as follows: G. George and JA Pearce II. But what is also noted that there is no interconnection between these two coauthors, making understand that the main search author to develop studies with them, but individualized, i.e., not involving these at $*$ Similar studies and not creating relationships academic and scientific research between them.

Figure 3 - Structure of nets - Authored with 2 coauthors



Source: Ucinet. 07/2015.

Figure 3 provides the formation of four chains, two with co-authorships that do not interconnect and two others where the coauthorships create partnerships with other coauthors, all being interconnected with Zahra. Example of the first two initial structures researches done by Zahra together with Kuratko and Jennings and others with Keil and Maula. As there is no connection between these two networks, one realizes that the above co-authors, being in each of its structures, develop contacts research together with Zahra.

In the third and fourth demonstration of the network structure, Neubaum as the co-author and his relationship with four co-authors in the study developed in partnership with Zahra and George as the co-author with four other co-authors, following similar model developed by Neubaum. Finally, Figure 4 shows the formation of networks involving three or more coauthoring researchers with Zahra.

\section{Figure 4 -Structure of nets - Authorship 3 coauthors}

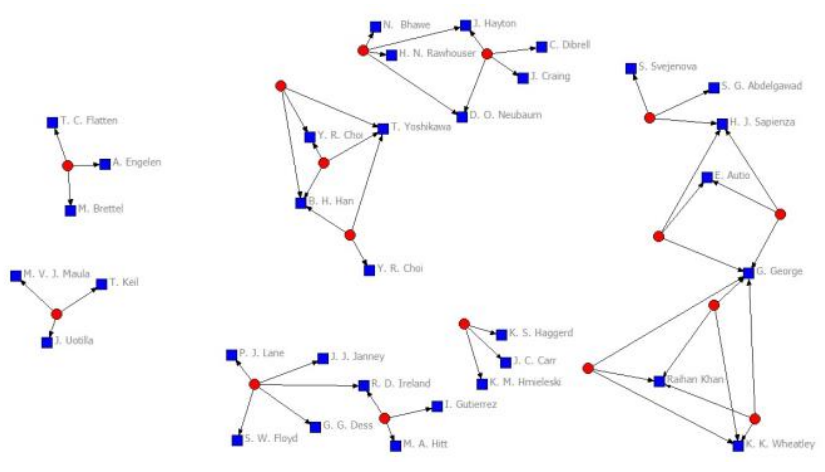

Source: Ucinet. 07/2015.

In the co-authorships with three or more researchers, it is highlighted the initial relationship with George Zahra, Yoshikawa and Han. As the first co-author has no correlation with the following two coauthors, even so, it is clear that the latter two have correlations with each other and at the end, the three co-authors were the ones that had partnerships in research by Zahra when the participation of three or more co-authors. It is also worth considering that the studies made between Zahra and George, other co-authors were also important, getting directions and participation in research. These are Khan, Wheatley and Sapienza, noting that when Zahra publishes with George, these coauthors also have coparticipation.

By analyzing the 160 study subjects, where the targets were developed individually and Many were made collectively between Shaker Zahra and other participants in the direction of facing entrepreneurship. It was known then that the total analyzed of 35 had entrepreneurship as a central theme, and these were as elaborate as to its authorship: 13 studies were conducted individually and 22 with the participation of other researchers. The higher incidence of events of these studies was in the years 1999-2003.

In these 35 articles, the topics related to entrepreneurship were: corporate entrepreneurship, international entrepreneurship, financial performance, environment, skills, 
organizational capacity, global economy, governance, competitiveness, international expansion, and culture, business advantage, building theories, entrepreneurship education, ecosystems and global innovation.

As for the 13 individual studies by Zahra, the issues that most had correlation with entrepreneurship were: financial performance, strategies, theory building, public management, market orientation, organizational learning and governance. The themes within their individual research in relation to the collective research, only 7 were studies in which Zahra developed in partnership with other researchers, taking place between the years of 1999-2005.

Another important information obtained in the analysis corresponds to the names of journals Shaker Zahra published his studies. In all, the 160 reviewed scientific articles that represented 29 years of research; Zahra got publications in 55 different journals in which these are shown in Table 3.

\section{Table 3 - Name of journals and number of publications}

\begin{tabular}{|c|c|}
\hline Regular Name & $\begin{array}{c}\text { No. } \\
\text { publications }\end{array}$ \\
\hline Journal of Business Venturing & 17 \\
\hline Entrepreneurship: Theory and Practice & 16 \\
\hline Journal of Management & 12 \\
\hline Academy of Management Journal & 8 \\
\hline Academy of Management Executive & 8 \\
\hline Strategic Management Journal & 7 \\
\hline Academy of Management Proceedings & 7 \\
\hline Journal of Management Studies & 6 \\
\hline European Management Journal & 6 \\
\hline Academy of Management Review & 6 \\
\hline Journal of Business Ethics & 5 \\
\hline International Business Journal & 4 \\
\hline Frontiers of Entrepreneurship Research & 4 \\
\hline Journal of High Technology Management Research & 3 \\
\hline Family Business Review & 3 \\
\hline Strategic Entrepreneurship Journal & 3 \\
\hline Long Range Planning & two \\
\hline Academy of Management Best Paper Conference & two \\
\hline Journal of International Business Studies & two \\
\hline Small Business Economics & two \\
\hline Journal of World Business & two \\
\hline Corporate Governance: An International Review & two \\
\hline International Journal of Commerce and Management & 1 \\
\hline Advanced Management Journal & 1 \\
\hline
\end{tabular}

Revista de Negócios, v. 20, n. 4, p. 44-6o, October, 2015.

\begin{tabular}{|c|c|}
\hline Institute of Industrial Engineers & 1 \\
\hline Journal of Consumer Marketing & 1 \\
\hline Academy of Journal & 1 \\
\hline Confer. Proceedings, Entrepr, Academy of Management & 1 \\
\hline Journal of Small Business Management & 1 \\
\hline Administrative Science Quarterly & 1 \\
\hline Strategic Entrepreneurship: creating a new mindset & 1 \\
\hline Information Systems Research & 1 \\
\hline Global Entrepreneurship Monitor & 1 \\
\hline Journal of the Iberoamerican Acad. of Management & 1 \\
\hline Int. J. Technology Management & 1 \\
\hline Innovating Strategy Processes & 1 \\
\hline Emerald Group Publishing Limited & 1 \\
\hline Handbook of Research on Family Business & 1 \\
\hline AIM Research Working Paper Series & 1 \\
\hline organizational Dynamics & 1 \\
\hline Entrepreneurial Strategic Processes & 1 \\
\hline Journal of Business Research & 1 \\
\hline Industrial and Corporate Change & 1 \\
\hline Human Relations & 1 \\
\hline Journal of Management Strategy and & 1 \\
\hline Entrepreneurship and Higher Education OECD Publishing & 1 \\
\hline Research Policy & 1 \\
\hline British Journal of Management & 1 \\
\hline AMS View & 1 \\
\hline Journal of Management Inquiry & 1 \\
\hline Entrepreneurship Research Journal & 1 \\
\hline Academy of Management Learning \& Education & 1 \\
\hline Business Horizons & 1 \\
\hline Journal of Leadership \& Organizational Studies & 1 \\
\hline Organization Science & 1 \\
\hline
\end{tabular}

2015.

The journal 'Journal of Business Venturing was the most published Zahra's studies, both individual studies (8 publications) as well as with co-authors (9 publications). Upon receiving 17 publications, the representative that it was acquired $10.63 \%$ of the 160 analyzed publications.

Already, the journal 'Entrepreneurship: Theory and Practice', the second that received publications, its representativeness was at $12.30 \%$ of the total analyzed. What draws attention on this figure is that it represents 16 publications and, of these, 15 were conducted with the participation of co-authors, being only 1 where Zahra published the study individually. The third prominent journal is the Journal of Management, having received 12 publications $(7.5 \%$ and 
representativeness) of 160 analyzed.

At the end of the first group of subjects analyzed, there is still the analysis of keywords. Considering the 160 studies analyzed, 111 of them did not present or did not meet key words quoted, representing $69.38 \%$ of those articles. In the 49 remaining articles were obtained keywords, 39 were made by Zahra in partnership with co-authors and 10 were cited exclusively. Altogether, these 49 articles were found 134 keywords, 98 in the collective and the individual articles 36 articles.

The keywords that occurred most in 39 scientific articles made by Zahra with co-authors were:

Table 4 - Main keywords

\begin{tabular}{c|c}
\hline Keywords & Quantity quotes \\
\hline Absorption capacity & 7 quotes \\
\hline entrepreneurship & 6 quotes \\
\hline Innovation & 6 quotes \\
\hline governance & 5 quotes \\
\hline alliances & 5 quotes \\
\hline internationalization & 4 quotes \\
\hline Knowledge & 4 quotes \\
\hline ecosystem & 4 quotes \\
\hline
\end{tabular}

2015.

Source: Adapted by the author. July /

In 10 articles developed exclusively by Zahra, the most cited keywords were: entrepreneurship (3 citations); learning (3 citations); action strategies (2 quotes); performance of the company (2 quotes); family business (2 quotes); production geared to the market ( 2 quotes) and governance ( 2 quotes).

It is noticed that the keywords most cited in Zahra publications with his co-authors, only two were repeated in the individual publications, which are: governance and entrepreneurship. This makes us understand that the focus and direction of the author's research with his co-authors tend to be differentiated when defining the study subjects was seen by the individual perspective of the same. With regard to governance, Malo (2001), making a link between the governance structure and the concept of collective entrepreneur emphasizes that decision-making is developed to the extent that the actors in each instance act guided by a set of relevant principles a venture of cooperative and collective nature.

The second group of analysis is established to present the studies by Zahra, is directed in the statement of the methods used in their research The first issue to be addressed is fixed in the indication of the dependent and independent variables. Of the 160 studies analyzed, 80 of those had information both dependent variables as independent variables or of one or another, representing $50 \%$ of the analysis made in this regard.

To achieve these core issues, there was a longitudinal scan of the 160 papers analyzed between the years 1985-2014, seeking to get the issues that most were studied by Zahra, thus reaching the number of 80 studies with indications of dependent variables and independent. In this analysis, 80 studies allowed to reach eight core subjects, where these are known as: orientation and strategic processes, financial performance, international entrepreneurship, corporate entrepreneurship, governance, internationalization, family entrepreneurship and business opportunities, the presentation of the same is given by determining each subject that the author seeks in order to search. For more specific knowledge of this information, Table 5 presents the central theme name, the number of variables (dependent and independent) in each theme and the name of the variables.

Revista de Negócios, v. 20, n. 4, p. 44-6o, October, 2015. 
Table 5 - Variables for study topic researched by Shaker

Zahra

\begin{tabular}{|c|c|c|c|}
\hline $\begin{array}{l}\text { Study of } \\
\text { Central } \\
\text { Themes }\end{array}$ & $\begin{array}{l}\text { Studied } \\
\text { variables } \\
\text { (Total) } \\
\end{array}$ & Dependent variables & Independent variables \\
\hline $\begin{array}{l}\text { Guidance } \\
\text { and } \\
\text { strategic } \\
\text { process }\end{array}$ & 22 & $\begin{array}{c}\text { Age of the company; size; type of industry;management team } \\
\text { composition; power bases; beliefs and management goals;strategic } \\
\text { flexibility; competitive orientation of the company; number of } \\
\text { employees; Total sales growth; return on sales after taxes; domain; key role } \\
\text { in the ecosystem; strategic thought; factors that facilitate strategic } \\
\text { thinking; barriers of strategic thinking. }\end{array}$ & $\begin{array}{l}\text { Trading on the success of the } \\
\text { market; dominator } \\
\text { niche;entrepreneurs; new } \\
\text { learning } \\
\text { advantages; cognitive } \\
\text { limitations of the } \\
\text { entrepreneur; busy schedules. }\end{array}$ \\
\hline $\begin{array}{c}\text { financial } \\
\text { performan } \\
\text { ce }\end{array}$ & 17 & $\begin{array}{l}\text { Property type; phases of the business life cycle; complexity of internal } \\
\text { operations;corporate social responsibility; financial } \\
\text { performance; biotechnology; alliance between universities and } \\
\text { businesses;innovation; knowledge; productivity;profitability; revenue } \\
\text { growth. }\end{array}$ & $\begin{array}{l}\text { Features of the external } \\
\text { environment; Type of } \\
\text { Company;technological } \\
\text { orientation; high tech; low } \\
\text { technology. }\end{array}$ \\
\hline $\begin{array}{c}\text { internatio } \\
\text { nal } \\
\text { entrepren } \\
\text { eurship }\end{array}$ & 6 & $\begin{array}{l}\text { entrepreneurship; internationalization;knowledge; organizational } \\
\text { learning;Skills; accept risks. }\end{array}$ & \\
\hline $\begin{array}{c}\text { corporate } \\
\text { entrepren } \\
\text { eurship }\end{array}$ & 33 & $\begin{array}{l}\text { Strategy; environmental considerations;organizational factors; financial } \\
\text { performance; entrepreneurship; product innovation; risk } \\
\text { taking; liquidity; debt to equity; non-durable capital goods;emphasis on } \\
\text { proprietary activities; support management; reinforcement } \\
\text { rewards;availability; organizational boundaries;sustainable } \\
\text { regeneration; reset domain; the role of leadership; social exchange. }\end{array}$ & $\begin{array}{l}\text { Dynamism; hostility; heteroge } \\
\text { neity; financial } \\
\text { goals; competitive } \\
\text { advantage;marketing } \\
\text { objectives; social } \\
\text { advantage; scanning;different } \\
\text { iation; integration;control; cu } \\
\text { lture centered on the } \\
\text { person; communication; succ } \\
\text { ess in culturing value. } \\
\end{array}$ \\
\hline $\begin{array}{c}\text { Governan } \\
\text { ce } \\
\end{array}$ & 11 & $\begin{array}{l}\text { Social interaction; assets of human capital;assets of property; relational } \\
\text { goods; the company's age; company size; spent } \\
\text { abroad; internationalization. }\end{array}$ & $\begin{array}{c}\text { Outsider property; possession } \\
\text { of the executive; long and } \\
\text { short-term institutional. }\end{array}$ \\
\hline $\begin{array}{l}\text { internatio } \\
\text { nalization }\end{array}$ & 28 & $\begin{array}{l}\text { sales percentage in the foreign market;number of countries that the } \\
\text { Company serves; parts of the export; parts of importation; parts of the } \\
\text { advertising budget directed to international markets; the share of the costs } \\
\text { of R \& D abroad; Parts of production made } \\
\text { abroad; heterogeneity;munificence; professional manufacturing;services, } \\
\text { retail and wholesale; the company's age; the proportion generated by } \\
\text { international operations revenue; modal commitment; High industrial } \\
\text { technology;intensity in R \& D; patent; experience and international } \\
\text { levels; industry growth rate;concentration; foreign penetration;government } \\
\text { aid; current liquidity;consumer non-durables company;technology } \\
\text { industry; international alliances; revenue growth; number of companies } \\
\text { have introduced products in foreign markets. }\end{array}$ & $\begin{array}{l}\text { Property of the } \\
\text { CEO;institutional } \\
\text { ownership; share } \\
\text { capital; input mode. }\end{array}$ \\
\hline $\begin{array}{c}\text { family } \\
\text { entrepren } \\
\text { eurship }\end{array}$ & 24 & $\begin{array}{l}\text { Family institutions; family size; shared vision; use of national } \\
\text { alliances; use of alliances in foreign markets; entry into new domestic } \\
\text { markets; entry into new foreign markets; investment in emerging radical } \\
\text { technology; introduction and product innovation radical; commitment of } \\
\text { family culture; culture-oriented management;active participation of the } \\
\text { family in the business; no active participation of family members in the } \\
\text { business; but with interest;amplitude; depth; speed of organizational } \\
\text { learning. }\end{array}$ & $\begin{array}{l}\text { family involvement; family } \\
\text { property; CEO is also the } \\
\text { founder; mandate of the } \\
\text { CEO;family } \\
\text { property; number of family } \\
\text { generations; the company's } \\
\text { status indicators. }\end{array}$ \\
\hline $\begin{array}{c}\text { business } \\
\text { opportunit } \\
\text { ies } \\
\end{array}$ & 29 & $\begin{array}{c}\text { Slack resources; age of the Joint Venture;corporate risk; technological } \\
\text { leadership;internal dynamic technology licensing;intensity of rivalry; type } \\
\text { of regime;innovation; product line and amplitude;product } \\
\text { differentiation; Modularity of the product; sales growth; distinction } \\
\text { between the growth of domestic and international sales; market } \\
\text { definition; cooperation;communication; troubleshooting;performance; perf } \\
\text { ormance and strategic variety; average return on equity; product }\end{array}$ & $\begin{array}{c}\text { Inclusion of expenditure on R } \\
\text { \& D; employment of } \\
\text { scientists and engineers; the } \\
\text { R \& D portfolio; the number } \\
\text { of products; the use of } \\
\text { patents; origin and } \\
\text { development of }\end{array}$ \\
\hline
\end{tabular}

Revista de Negócios, v. 20, n. 4, p. 44-6o, October, 2015. 


\begin{tabular}{c|c|c|c}
\hline & & development in new companies. & $\begin{array}{c}\text { ACAP; vertical } \\
\text { alliances; horizontal } \\
\text { alliances. }\end{array}$ \\
\hline
\end{tabular}

Source: Adapted by the author. July / 2015.

It is noticed that there were several issues presented as 'dependent variables' and as 'independent variables', stating that the studies developed by Zahra, both individually and collectively, have different central themes but with certain variables that the end were similar or close in terms of studies.

Regarding the type of research, analysis or methods and methodological techniques that 160 articles analyzed studies were submitted, the first description that is, turns on the demonstration of reliability analysis, measurement scales, and hypothesis testing. These three techniques were found in 78 studies, representing $48.75 \%$ of the scientific material available. In the reliability analysis, the main was Cronbach's alpha coefficient. The measurement scale that stood out was the Likert Scale and hypothesis testing; the highlight was the T test, X2 test and single factor test Harman. The latter test according to Souto and Rego (2007) assumes that, if there is a substantial amount of variance common method, then emerge one factor or a general factor that explain the most variance when all study variables are inserted into a factor analysis.

The types of research, analysis studies allowed finding 84 studies with information surrounding this event, representing $52.50 \%$. All of these studies allowed us to know 21 different types of searches made by Zahra and his coauthors. Therefore, the most used types of research were: empirical research, Miles-Snow research, cognitive research, exploratory research, email search and interview.

It is noticed that the direction and focus of Zahra was just to gather information for their research on events that were happening or happened and to enable it to better understanding and deepening their occurrence. This is confirmed in the research used in those cited in which the empirical research was highlighted. Therefore, allowing Zahra to know and describe facts and situations of social conditions experienced by people and organizations studied in his research. Demo (. 2000, p 21) adds, saying that "empirical research is dedicated to the treatment of empirical and factual face of reality; It produces and analyzes data, always proceeding by way of empirical and factual control".

Analysis methods were also presented in relation to the analyzed studies. Therefore, the 160 articles available, 69 of these $(43.40 \%)$ had or allowed to know the method of analysis, which are a total of 37 different models. The most frequently cited or used were regression analysis, moderate regression analysis, hierarchical regression analysis, confirmatory factor analysis, factor analysis, multivariate analysis of variance (MANOVA), multivariate analysis of covariance (MANCOVA), mixed univariance analysis (ANOVA) analysis of covariance (ANCOVA) and varimax rotation process. In individual studies Zahra, of the 37 studies, 19 of these have allowed to know the method used, with the highlight: analysis of variance (ANOVA), multivariate analysis of variance (MANOVA), multivariate analysis of covariance (MANCOVA), analysis of covariance ( ANCOVA) and factor analysis.

In the final phase of this study, there is still a public profile analysis analyzed, where the types of research, analysis or methods and methodological techniques could be tested and applied by Zahra. Initially it is clear that the author and his co-authors sought to collect data and information of all kinds of existing public business and active both in the United States but also in Europe and in Asian Continent. Having the focus of Zahra studies and his co-authors with core issues facing the guidance and strategic process, financial performance, international entrepreneurship, corporate entrepreneurship, governance, internationalization, family entrepreneurship and business opportunities, the profile of the publicinterviewed focused on professionals working in universities, family businesses, food, automotive, biotechnology, telecommunications, software, high and low technology, plastics, traded, post offices and even companies with less than 500 employees.

This focused public was found in 93 articles, representing $58.49 \%$ of the 160 articles analyzed. The most searched public were professionals working in companies that appear in

Revista de Negócios, v. 20, n. 4, p. 44-6o, October, 2015. 
the Fortune 500 and also in family businesses, manufacturing, and biotechnology, high and low tech, international, with fewer than 500 employees and companies with less than 8 years of existence. The studies carried out in these types of organizations occurred in Spanish companies, Danish, South Korean, Finnish and Israeli, which makes us understand that the analyses by this author occurs in several global regions, allowing to establish are these, global studies in the field of entrepreneurship, giving importance to scientific research and valuing the research of this subject in the academic and scientific context of the academy.

\section{Limitations}

In the period in which the collection and subsequent analysis of the data, we noticed some difficulties while limitations in their implementation. These difficulties and limitations passed both the scrutiny of obtaining articles as well as the execution of their analysis. From a final list of 209 possible products to be obtained and analyzed, the first limitation introduced was in obtaining the articles themselves, because due to lack of registration in some search portals, especially in the portal Capes, there was a limitation only showed in 160 articles.

The second limitation is halted by the fact that certain periodicals required buying dollar of your electronic file, where it prevented the acquisition of about 30 to 40 items.

A third limitation occurred in those articles in which their periodic asked username and password and these journals not being registered at the Regional University of Blumenau - FURB prevented the original document obtained. The fourth limitation was that certain articles only having the summaries available as making the depth of the analysis.

And, finally, the fifth limitation was the lack of guidance on the use of Ucinet 6 data software, in which the same handling learning was due to the application of trial and error attempts, in order to obtain the understanding usage and performing in the desired analysis, thereby, forming the co-authorship networks.

\section{Proposals for Future Studies}

This being one of the first bibliometric studies directed longitudinal investigation of a single author publications, it is proposed to study in a more specific way, the central theme of study related to 'corporate entrepreneurship' because this was one of the most researched central themes by Shaker Zahra.

It is also proposed to undertake further studies with all 160 articles available, to find out about these possible limitations and / or implementation difficulties and also to know about the direction of future research and the core subjects studied.

And the third proposal is directed to know more specifically, studies by leading coauthors Zahra, appointed by Donald O. Neubaum, Gerard George and Harry J. Sapienza, proposing longitudinal study of its academic and scientific historical publications, seeking to know the central themes of their research, comparing them with those of Zahra, aimed at developing new research materials.

\section{Main Conclusions}

The intention of understanding the path of scientific research developed by Shaker Zahra allowed the development of this longitudinal historical analysis, where they were shown the results of 29 years of academic studies through technical publications that portrayed the quest for knowledge in several areas correlated to the field entrepreneurship.

Being prepared developed by bibliometric technique, the study initially presented the concepts that allow knowledge about entrepreneurship and bibliometrics, making a relationship between them, in order to demonstrate through the literature review, the importance of linking these with scientific research.

Based on the data collection occurred in pursuit of academic portals like Capes Portal and Google Scholar Portal, they allowed us to obtain scientific material that allows the study. Were presented in the data analysis phase, the bibliometric and quantitative reading of Shaker Zahra publications between the years 1985-2014 through 160 publications that have taken place in 29 years of research. These statements were divided into two groups, the first being responsible for presenting and analyzing issues on the introductory structure of academic material as

Revista de Negócios, v. 20, n. 4, p. 44-6o, October, 2015. 
authorship, co-authorship, journal publication, year, coauthors gender, fields of study and keywords, getting the second group to demonstrate matters relating to the type of research, analysis or methods and methodological techniques.

Whereas, therefore, that the prospects of the study were to analyze the academic background and technical Zahra, it is understood that this goal was achieved. The statement of research data was presented in the form of networks and tables, and as a result, the descriptive analysis applied to each quantitative demonstration, which allowed knowledge of the paths and author of that research focuses.

It is hoped that this study can form the basis for new and future academic research involving longitudinal research of scientific publications from other authors, since as the bibliometric and longitudinal analysis of research Shaker Zahra, this study is considered a pioneer in the field of academic research.

\section{References}

ALMEIDA, E. R. de; ANDALÉCIO, A. M. L. Empreendedorismo e hotelaria como tema de pesquisa: um estudo bibliométrico das publicações do Enanpad de 2005 a 2011. Turismo \& Sociedade. Curitiba, v. 5, n. 2, p. 527-544, outubro de 2012.

BRAGA, G. M. Relações bibliométricas entre frente de pesquisa (research front) $a$ revisões de literatura: estudo aplicado a ciência da informação. Rio de Janeiro, IBICT, 1972, 37 p. (dissertação).

BRAGA, G. M. Dynamics of scientific communication: an application to science funding policy. Ph. D. Dissertation-Case Western Reserve University, 1977.

BRANCHER, I. B.; OLIVEIRA, E. M.; RONCON, A. Comportamento empreendedor: estudo bibliométrico da produção nacional e a influência de referencial teórico internacional. Internext - Revista Eletrônica de Negócios Internacionais da ESPM, São Paulo, v. 7, n. 1, p. 166-193, jan./jun. 2012.

BRUYAT, C. (1994), Contributions épistémologiques au domaine de l'entrepreneuriat, Revue Française de Gestion, 101, 113-125
BYGRAVE, W. D. The entrepreneurship paradigm (I): A philosophical look at its research methodologies. Entrepreneurship Theory and Practice, 14(1), p. 7-26, 1989a. 151

BYGRAVE, W. D. The entrepreneurship paradigm (II): chaos and catastrophes among quantum jumps. Entrepreneurship Theory and Practice, 14(2), p. 7-30, 1989b.

BYGRAVE, W. D.; HOFER, C. W. Theorizing about entrepreneurship. Entrepreneurship, theory and practice 16(2), 13-22. 1991.

CARLAND, J. W.; HOY, F.; BOULTON, W. R. Differentiating entrepreneurs from small business owners: a conceptualization. Academy of Management Review. v.9, n.2, p. 354-349, 1984.

CARTER, N.M.; GARTNER, W.B.; REYNOLDS, P.D. (1996). Exploring start-up event sequences. Journal of Business Venturing, 11, 151-166.

CHURCHILL, N. C.; LEWIS, V. L. Entrepreneurship research: Directions and methods 1985. Paper presented at the 1st Babson Conference on Entrepre-neurship. Philadelphia, PA, 1985.

SOUTO, Solange de Oliveira; REGO, José Arménio. Como as percepções de espírito de camaradagem explicam a felicidade dos colaboradores: o papel moderador da necessidade de pertença. XXXI Encontro da ANPAD. Rio de Janeiro (RJ), 22 a 26 de setembro de 2007.

DEMO, Pedro. Pesquisa e construção do conhecimento: metodologia científica no caminho de Habermas. Rio de Janeiro: Tempo Brasileiro, 1994.

DRUCKER, P. (1970), Entrepreneurship in Business Enterprise. Journal of Business Policy. Vol. 1.

FAIRTHORNE, R. A. Progress in documentation: empirical hyperbolic distributions for bibliometric description and prediction. Journal of documentation, 25 (4):31943,1969.

FERREIRA, Paulo Gitirana Gomes; MATTOS, Pedro Lincoln Carneiro Leão de. Empreendedorismo e práticas didáticas nos cursos de graduação em Administração: os estudantes levantam o problema. Anais do Enanpad, 2003. 
FIGUEIREDO, Laura Maia de. Distribuição da literatura geológica brasileira: estudo bibliométrico. Ciência da Informação, 2(1): 27-40,1973.

FILION, L. J. Vision et relations: clefs du succés de entrepreneur. Montréal: Éditions de l'entrepreneur, 1991.

GARTNER, William B. A Conceptual framework for describing the phenomenon of new venture Creation. Academy of management review, v.10 p. 696-706, 1985.

GARFIELD, E. ISI'S experience with ASCA a selective dissemination system. Journal of Chemical Documentation, 7:147-53, 1967.

GIAROLA, P. G.; FIATES, G. G.S.; DUTRA, A.; MARTINS, C.; LEITE, A. Empreendedorismo inovador gerado pelas universidades: mapeamento da produção científica. Revista Pensamentos Contemporâneos em Administração - RPCA. Rio de Janeiro, v. 7, n. 2, abr./jun. 2013, 41-60, 41.

GIMENEZ, Fernando A. P.; JUNIOR, Edmundo Inácio; SUSIN, Luzia A. de S. B. Uma investigação sobre as tendências do comportamento empreendedor. In: SOUZA, Eda Castro Lucas de. Empreendedorismo: competência essencial para pequenas e médias empresas. Brasília: ANPROTEC, 2001.

GOFFMAN, W. \& WARREN, K. S. Dispersion of papers among journals based on a mathematical analysis of to diverse medicai literature. Nature, 221 (5187) :1205-7, March, 1969.

HJERPPE, R. An outline of bibliometrics and citation analysis. Stockholm, Royal Institute of Technology, 1978. 82p.

IIZUKA， E. S.; WALCHHUTTER， S.; DIAS, M. R., BARBOSA, A. S. Empreendedorismo Social e Negócios Sociais: Revisão Crítica e Agenda de Pesquisa. XVII SEMEAD - Seminários em Administração. Outubro de 2014.

IKPAAHINDLI, Linus. An overview of bibliometrics: its measurements, laws and their applications. Libri, v. 35, n. 2, p. 163-177, june. 1985.

LIMA, Regina Célia Montenegro de. Estudo bibliométrico: análise de citações no periódico

'Scientometrics'. Ci. Inf., 13(1): 57-66, jan./jun. 1984.
LOPEZ PIÑERO, J. M. El análisis estatístico y sociométrico de Ia literatura científica. Valência, Centro de Documentación e Informática Medica, 1972. 82p.

LOW, M. B.; MACMILLAN, I. C. (1988). Entrepreneurship: Past research and future challenges. Journal of Management, 14(2): 139161.

MACIAS-CHAPULA, C. A. O papel da informetria e da cienciometria e sua perspectiva nacional e internacional. Ciência da Informação, v. 27, n. 2, p. 134-140, 1998.

MAIA, Maria José da Fonseca. As diversas interpretações da lei de Bradford. In: Estudos avançados em Biblioteconomia e Ciência da Informação. Brasília, ABDF, 1982 p.119-31.

MALO, M. C. (2001, Juillet). La gestion stratégique de la coopérative et de l'association de l'économie sociale. 1ére partie: L'entrepreneur et son environnement. Revue Internationale de L'Économie Sociale - RECMA, 281, pp. 84-95.

MARTINS, C.; FIATES, G. G. S.; DUTRA, A. LEITE, A. L. S.; GIAROLA, P. G. Empreendedorismo inovador gerado pelas incubadoras de base tecnológica: Mapeamento da produção científica até 2013. Revista de Negócios, ISSN 1980-4431, Blumenau, Brasil, v. 19, n. 2, p. 86-108, Abril/Junho de 2014.

McCLELLAND, D.C. The achieving society. Princeton, N. J. Van Nostrand, 1961. See also the new introduction to the book New York, Invington Publishers, 1976.

MOREIRA, H. S. A.; MOREIRA, M. A.; CASTRO SILVA, W. A. Dez anos de pesquisa em empreendedorismo apresentados nos Enanpads de 2003 a 2012: análise dos autores engajados na área. Revista de Empreendedorismo e Gestão de Pequenas Empresas, v. 3, n.1, p. 33-55, 2014.

OLIVEIRA, Fabiana Morais de. Empreendedorismo: teoria e prática. Curso Vip de Administração Instituto de Pós Graduação IPOG. Especialize - Revista on line. Maio/2012.

OLIVEIRA, D. S.; CAMARGO FILHO, A., PEIXOTO, N. P.; COELHO, R. L. F. (2014). Marketing Empreendedor: um estudo bibliométrico em bases de dados internacionais. In: VIII EGEPE - Encontro de Estudos Sobre Empreendedorismo e Gestão de Pequenas Empresas, Goiânia.

Revista de Negócios, v. 20, n. 4, p. 44-6o, October, 2015. 
PEREIRA, H. J., SANTOS, S. A. dos. Criando seu próprio negócio: como desenvolver o potencial empreendedor. São Paulo: SEBRAE/FIA/USP, 1995.

PINHEIRO, Lena Vânia R. Lei de Bradford: uma reformulação conceituai. Rio de Janeiro, IBICT, 1982. 82p. (dissertação de mestrado).

$$
\text { PRITCHARD, A. Statistical }
$$

bibliography or bibliometrics? Journal of documentation, 25: 348-9, 1969.

RAVELLI, Ana Paula Xavier et al. A produção do conhecimento em enfermagem e envelhecimento: estudo bibliométrico. Texto Contexto Enferm, Florianópolis, 2009 Jul-Set; 18(3): 506-12.

REMENYI, D.; WILLIAMN, B.; MONEY, A.; SWARTZ, E. Doing Research in Business and Management: An Introduction to Process and Method. London: Sage Publications, 1998.

ROCHA, D. da; WALTER, S. A.; SILVA, E. D. da; GIMENEZ, F. A. P. Processo de formação de estratégia em pequenas empresas: um estudo bibliométrico e sociométrico. Revista da Micro e Pequena Empresa, Campo Limpo Paulista, v.5, n.1, p.102-119.2011 (Jan/Abr).

RODRIGUES, Maria de Paz Lins. Estudo das citações constantes das dissertações de mestrado em Ciência da Informação do IBICT/ UFRJ. Rio de Janeiro, IBICT, 1981. 89p. (dissertação de mestrado).

SARACEVIC, T. Introduction to Information science. New York, Bowker, 1970, $781 \mathrm{p}$.

SPINAK, E. Indicadores cienciométricos. Ciência da Informação, v. 27, n.2, p. 141-148, 1998.

SCHUMPETER, J.A. Business Cycles, Mc-Graw Hills, NY, 1964.

SILVA, Fernanda Reis da; NASSIF, Vânia Maria Jorge. Empreendedorismo sob a ótica dos aspectos cognitivo: um estudo bibliométrico de análise de citação e co-citação. Anais do III SINGEP e II S2IS. São Paulo (SP). Brasil. 09, 10 e 11/11/2014.

SILVEIRA, Amélia. PRODUÇÃO CIENTÍFICA EM EMPREENDEDORISMO FEMININO: análise dos periódicos indexados no Social Sciences Citation Index, 2006 - jul. 2008 In: GIMENEZ, Fernando; FERREIRA, Jane
Mendes; RAMOS, Simone Cristina. Col.: SCHERNER, Maria Luiza Trevizan; CARVALHO, Gleide Morais de. Empreendedorismo e estratégia de empresas de pequeno porte - 3Es2Ps. Org.: Curitiba: Champagnat, 2010.

VAN DE VEN, A. H.; HUDSON, R.; SCHROEDER, D. M. (1984). Designing new business star ups: Entrepreneurial, organizational, and ecological considerations. Journal of Management, vol. 10, n1, p. 87.

VICKERY, R. C. Bradford's of scattering. Journal of Documentation, 4 (3) :198203, Dec. 1948.

ZAHRA, S.A. (1986). A canonical analysis of corporate entrepreneurship: antecedents and impact on performance. Proceedings of National Academy of Management, vol. 46, pp. 71-75.

ZAHRA, S.A. (2003). International expansion of U.S. manufacturing family businesses: The effect of ownership and involvement. Journal of Business Venturing, 18(4), 495-512.

WERUTSKY, V. DB. G.; LEZANA, A. G. R.; GARCIA, J. R.; VASCONCELOS, A. M. de. O papel do intraempreendedor na gestão da inovação: reflexões a partir de um estudo teórico. XXXII Encontro Nacional De Engenharia De Produção. Desenvolvimento Sustentável e Responsabilidade Social: As Contribuições da Engenharia de Produção Bento Gonçalves, RS, Brasil, 15 a 18 de outubro de 2012.

Revista de Negócios, v. 20, n. 4, p. 44-6o, October, 2015. 